https://jurnal.unigal.ac.id/index.php/JKG/article/view/4536

\title{
GAMBARAN PENGETAHUAN KELUARGA TENTANG CARA PENCEGAHAN PENULARAN PENYAKIT TB PARU DI WILAYAH KERJA PUSKESMAS BAREGBEG KECAMATAN BAREGBEG TAHUN 2018
}

\author{
Emen Gunawan \\ UPTD Puskesmas Baregbeg \\ (Sejarah artikel: Diserahkan Mei 2020, Diterima Juni 2020, Diterbitkan Juli 2020)
}

\begin{abstract}
ABSTRAK
Pembangunan kesehatan ditujukan untuk meningkatkan kesadaran, kemauan, dan kemampuan hidup sehat bagi masyarakat yang setinggi-tingginya, sebagai investasi bagi pembangunan sumberdaya manusia yang produktif secara sosial dan ekonomis. Upaya dalam penanggulangan penyakit tuberkolosis masih terus dilakukan, namun dalam perjalananya banyak hambatan dalam upaya tersebut, salah satunya adalah dampak ketediak berhasilan pengobatan pasien tuberculosis. Penelitian ini bertujuan untuk mengetahui gambaran pengetahuan keluarga tentang cara pencegahan penyakit TB Paru. Desain penelitian ini menggunakan survey deskriptif dengan total sampel sebanyak 26 responden. Hasil penelitian menunjukan bahwa Pengetahuan keluarga pasien tentang pencegahan penularan $\mathrm{Tb}$ paru pada kategori baik.
\end{abstract}

\section{Kata Kunci: TB, Pengetahuan Keluarga, UPTD Puskesmas Baregbeg}

\section{PENDAHULUAN}

Pembangunan kesehatan ditujukan untuk meningkatkan kesadaran, kemauan, dan kemampuan hidup sehat bagi masyarakat yang setinggi-tingginya, sebagai investasi bagi pembangunan sumberdaya manusia yang produktif secara sosial dan ekonomis (Anonim,2009). Upaya kesehatan diselenggarakan dalam bentuk kegiatan dengan pendekatan promotif, preventif, kuratif, dan rehabilitatif yang dilaksanakan secara terpadu, menyeluruh dan berkesinambungan, termasuk pencapaian Millenium Development Goals (MDG's) untuk memerangi penyakit menular seperti TB Paru (PDPI 2011).

TB Paru disebabkan oleh Mycobacterium tuberkulosis. Penularan penyakit ini melalui perantaraan ludah atau dahak penderita yang mengandung basil tuberkulosis paru. Pada saat penderita batuk, butir-butir air ludah beterbangan di udara dan terhisap oleh orang sehat, sehinga masuk ke dalam paru-parunya, yang kemudian meyebabkan penyakit tuberkulosis. Jika seseorang telah terjangkit bakteri penyebab tuberkulosis, akan barakibat buruk, seperti menurunkan daya kerja atau produktivitas kerja, menularkan kepada orang lain terutama pada keluarga yang bertempat tinggal serumah (Naga, 2014).
Pengetahuan keluarga penderita tuberkulosis adalah semua informasi yang diperoleh keluarga penderita tuberkulosis mengenai program pengobatan. (Notoatmodjo, 2010). Keluarga dapat menjadi Pengawas Minum Obat (PMO) yang mempunyai tugas melakukan pengawasan terhadap pasien dalam hal minum obat dan memberikan dorongan terhadap pasien untuk berobat secara teratur hingga selesai (PDPI, 2011). Tuberkulosis dapat terjadi karena kurangnya pengetahuan keluarga. Dalam hal ini bagaimana seharusnya keluarga klien yang terdiagnosa mengetahui secara jelas dan benar apa sebenarnya penyakit tuberkulosis ini dan bagaimana cara pencegahannya (Isminah, 2004).

Keluarga sangat menentukan keberhasilan pengobatan. Terlebih dalam mencegah penularannya, jika keluarga klien yang terdiagnosa TB Paru mengerti apa yang sebenanya dilakukan keluarga juga bisa dan mampu melindungi dirinya dan anggota keluarga lainnya. Jika perilakunya baik maka akan membawa dampak positif bagi pencegahan penularan Tuberkulosis (Notoatmodjo, 2010). Pencegahan penularan TB paru diantaranya adalah menutup mulut bila batuk dan bersin, memakai masker, membuang dahak tidak sembarangan tempat, memisahkan alat makan dan 
Jurnal Keperawatan Galuh, Vol.2 No.2 (2020) 61 - 64

minum penderita, untuk bayi diberikan imunisasi BCG dan teratur minum obat (DepKes RI, 2004).

Pengobatan TB Paru terbagi menjadi 2 fase yaitu fase intensif (2-3 bulan) dan fase lanjutan (47 bulan ). Strategi penanggulangan TB dikenal sebagai Directly Observed Treatment Shortcourse (DOTS) adalah pengobatan TB dengan Obat Anti TB (OAT) jangka pendek di bawah pengawasan langsung oleh keluarga yang berperan sebagai Pengawas Menelan Obat (PMO), khususnya dalam dua bulan pertama di mana penderita harus minum obat setiap hari (Muttaqin, 2008).

\section{METODE PENELITIAN}

Jenis penelitian yang digunakan adalah penelitian survey deskriptif dimana peneliti menggambarkan pengetahuan keluarga penderita TB Paru tentang pencegahan penyakit TB Paru.

semua keluarga pasien yang menderita penyakit TB Paru di wilayah kerja UPTD
Puskesmas Baregbeg dengan jumlah 26 orang. Sampel penelitian ini adalah semua pasien TB yang positif dengan tekhinik total sampling. Penelitian ini dilaksanakan di wilayah kerja UPTD Puskesmas Baregbeg. Penelitian ini dilaksanakan mulai dari Dalam penelitian ini proses pengembalian dan pengumpulan data diperoleh dengan lembar observasi kuisioner meliputi karakteristik seperti usia, jenis kelamin, pekerjaan, pendidikan, dan pengetahuan.

Variabel dalam penelitian mengunakkan mono variabel atau variabel tunggal yaitu pengetahuan keluarga penderita TB Paru tentang pencegahan penyakit Tuberkulosis Paru.

Teknik pengumpulan data pada penelitian ini yaitu menggunakkan kuisioner dengan sumber Data Primer data yang diperoleh langsung dari keluarga dan Data Sekunder data yang diperoleh dari UPTD Puskesmas Baregbeg.

\section{HASIL PENELITIAN}

Tabel 1

Distribusi Responden Berdasarkan Jenis Kelamin

\begin{tabular}{cccc} 
No & Jenis kelamin & Frekuensi & Persentasi \% \\
\hline 1 & Laki-laki & 12 & 46,2 \\
2 & Perempuan & 14 & 53,8 \\
\hline & Total & 26 & 100
\end{tabular}

Tabel 1 menunjukan bahwa 46,2\% berjenis kelamin laki-laki dan 53,8\% berjenis kelamin perempuan.

Tabel 2

Distribusi Responden Berdasarkan Umur

\begin{tabular}{cccc} 
No & Golongan umur & Frekuensi & Persentasi (\%) \\
\hline 1 & $17-25$ & 6 & 23,1 \\
2 & $26-35$ & 4 & 15,4 \\
3 & $36-45$ & 7 & 26,9 \\
4 & $46-55$ & 7 & 26.9 \\
5 & $56-65$ & 2 & 7,7 \\
\hline & Total & 26 & 100
\end{tabular}

Tabel 2 Menunjukan bahwa golongan umur paling banyak adalah 36-45 tahun 7 responden $(26,9 \%)$ dan $46-55$ tahun 7 responden $(26,9 \%)$ dan golongan umur yang paling sedikit adalah 56-65 tahun 2 responden $(7,7 \%)$.

Tabel 3

Distribusi Responden Berdasarkan Pendidikan Terakhir

\begin{tabular}{cccc} 
No & $\begin{array}{c}\text { Pendidikan } \\
\text { terakhir }\end{array}$ & Frekuensi & Persentasi (\%) \\
\hline 1 & SD & 2 & 7,7 \\
2 & SMP & 9 & 34,6 \\
3 & SMA/SMK & 11 & 42,3 \\
4 & S1 & 4 & 15,4 \\
\hline & Total & 26 & 100
\end{tabular}


Tabel 3. Menunujukan bahwa responden dengan Pendidikan terakhir terbanyak SMA/SMK 9 responden $(42,3 \%)$, SMP 11 responden $(34,6 \%), \mathrm{S} 14$ responden $(15,4 \%)$ dan yang paling sedikit SD 2 responden $(7,7 \%)$

Tabel 4

Distribusi Responden Berdasarkan Jenis

\begin{tabular}{clcc} 
No & \multicolumn{1}{c}{ Pekerjaan } & Frekuensi & $\begin{array}{c}\text { Persentasi } \\
(\%)\end{array}$ \\
\hline 1 & Ibu rumah tangga & 9 & 34,6 \\
2 & Tukang & 3 & 11,5 \\
3 & Advokad & 1 & 3,9 \\
4 & Swasta & 3 & 11,5 \\
5 & Pendeta & 1 & 3,9 \\
6 & PNS & 3 & 11,5 \\
7 & Wiraswasta & 2 & 7,7 \\
8 & Tidak bekerja & 4 & 15,4 \\
\hline \multicolumn{2}{r}{ Total } & 26 & 100
\end{tabular}

Tabel 4 menunjukan bahwa paling banyak responden mempunyai jenis pekerjaan sebagai ibu rumah tangga 9 responden $(34,5 \%)$ dan yang paling sedikit Advokad 1 responden $(3,9 \%)$ dan pendeta 1 responden $(3,9 \%)$.

Tabel 5

Distribusi Responden Berdasarkan Pengatahuan

\begin{tabular}{cccc} 
No & Pengetahuan & Frekuensi & Persentasi (\%) \\
\hline 1 & Baik & 15 & 57,7 \\
2 & Cukup & 8 & 30,8 \\
3 & Kurang & 3 & 11,5 \\
\hline & Total & 26 & 100
\end{tabular}

Tabel 5 menunjukan bahwa 15 responden $(57,7 \%)$ dalam kategori baik, 8 responden $(30,8 \%)$ dalam kategori cukup dan 3 responden dalam kategori kurang (11,5\%).

Berdasarakan data yang telah dikumpulkan dari 26 responden, ditabulasi dan telah disajikan dalam bentuk tabel distribusi frekuensi diatas, maka dapat diuraikan hasil penelitian sebagai berikut

\section{Karakteristik responden}

Hasil penelitian didapatkan pada tabel 2 menunjukan bahwa responden terbanyak dalam penelitian ini berumur 36-45 tahun 7 responden (26,9\%) dan 46-55 tahun 7 responden $(26,9 \%)$. Menurut Depkes RI (2009) 36-45 tahun masuk dalam usia dewasa akhir dan 46-55 tahun masuk dalam usia lansia awal, peneliti beranggapan hal ini disebabkan karena semakin dewasa umur seseorang maka akan semakin banyak pengalaman yang diperoleh tentang pencegahan penyakit $\mathrm{Tb}$ paru. Umur yang masih tergolong mudah kemungkinan juga kurang menerima informasi tentang kesehatan dalam hal ini penyakit TB paru. Umur adalah waktu yang dihitung sejak lahir sampai penelitian ini dilakukan

Jika ditinjau dari pendidikan pada tabel 3 menunujukan bahwa responden dengan pendidikan terakhir terbanyak SMA/SMK 9 responden $(42,3 \%)$, SMP 11 responden $(34,6 \%)$, S1 4 responden $(15,4 \%)$ dan yang paling sedikit SD 2 responden $(7,7 \%)$. Hal ini terbukti bahwa semakin tinggi pendidikan seseorang makin mudah pula menerima informasi dan makin baik pula pengetahuan yang di milikinya. Menurut Notoadmojo (2010), mengemukakan bahwa seseorang yang berpendidikan tinggi lebih mudah menerima ide baru atau informasi serta lebih mudah memahami apa yang disampaikan, semakin tinggi tingkat pendidikan seseorang semakin tinggi 
Jurnal Keperawatan Galuh, Vol.2 No.2 (2020) 61 - 64

pula tingkat pengetahuan sehingga kebutuhan akan pentingnya pelayanan kesehatan semakin tinggi pula.

Bila di lihat dari pekerjaan hasil penelitian yang didapatkan bahwa dari jenis pekerjaan responden yang paling banyak yaitu sebagai ibu rumah tangga 9 responden $(34,5 \%)$ dan yang paling sedikit Advokad 1 responden (3,9\%) dan pendeta 1 responden $(3,9 \%)$. Pekerjaan ialah kegiatan fisik dan mental manusia untuk menghasilkan barang atau jasa bagi orang lain maupun bagi dirinya yang dilakukan atas kemauannya sendiri atau dibawah perintah orang lain dengan menerima upah atau tidak. Menurut Anjaryani (2009), pekerjaan adalah aktifitas pekerjaan keluarga yang menghasilkan gaji/upah/honor atas pekerjaan tersebut.

\section{PEMBAHASAN}

Berdasarkan penelitian menunjukan hasil pengetahuan 15 responden $(57,7 \%)$ dalam kategori baik, 8 responden $(30,8 \%)$ dalam kategori cukup dan 3 responden dalam kategori kurang $(11,5 \%)$. Dan dari hasil diatas dapat dilihat bahwa pengetahuan responden tentang pencegahan penularan penyakit TB paru kategori baik 15 responden $(57,7 \%)$. Hal tersebut sejalan dengan penelitian terkait yang dilakukan oleh Wahyudi tahun 2006 tentang gambaran pengetahuan keluarga tentang cara pencegahan TB paru di ruang G4 Tropik RSUD Prof. Dr. H. Aloei Saboe Kota Gorontalo dimana 52,1\% responden kategori baik. Menurut Notoadmodjo (2010), pengetahuan lebih tergantung pada paparan informasi yang didapat seseorang mengenai suatu hal. Sehingga orang tersebut lebih termotivasi untuk mendapatkan informasi serta mengakses berbagai sumber informasi yang ada. Namun masih terdapat 3 responden $(11,5 \%)$ dalam kategori kurang. Peneliti berasumsi bahwa pendidikan kesehatan yang dilakukan oleh dokter dan perawat cukup efektif walaupun belum menunjukkan hasil yang maksimal, seharusnya upaya tenaga kesehatan lebih efektif lagi melalui penyuluhan-penyuluhan dan konseling serta memberikan pemahaman yang lebih mendalam lagi bagi keluarga. Pengetahuan dapat diartikan sebagai kumpulan informasi yang dipahami, yang diperoleh dari proses belajar selama hidup dan dapat digunakan sewaktu-waktu sebagai alat penyesuaian diri (Suharso, 2005).

\section{SIMPULAN}

Berdasarkan hasil penelitian pengetahuan keluarga tentang pencegahan penularan penyakit TB paru dapat disimpulkan bahwa: Pengetahuan keluarga pasien tentang pencegahan penularan $\mathrm{Tb}$ paru pada kategori baik 15 responden $(57,7 \%)$

\section{DAFTAR PUSTAKA}

Depkes, RI 2004. Pedoman Nasional Penanggulangan Tuberkulosis, Jakarta

Isminah 2004. Pencegahan Tuberkulosis di Masyarakat. http://www.medicastore.com

Depkes RI (2009). Profil Kesehatan Indonesia. Jakarta: Depertemen Republik Indonesia

Muttaqin, Arif. 2008. Buku Ajar Asuhan Keperawatan Klien dengan Gannguan Sistem Pernafasan. Salemba Medika, Jakarta

Naga, Soleh. 2014. Buku Panduan Lengkap Ilmu Penyakit Dalam. Diva Press, Jogjakarta 